\title{
Pengaruh Program Pengampunan Pajak Terhadap Efektivitas Penerimaan Pajak di Indonesia
}

\author{
Olivia Adam ${ }^{1)}$, Hartati Tuli ${ }^{2}$, Siti Pratiwi Husain ${ }^{3)}$ \\ Universitas Negeri Gorontalo \\ 1olivia.adam@gmail.com, 2hartati.tuli@gmail.com, 3pratiwihusain04@gmail.com
}

\begin{abstract}
This study aims at testing the influence of tax amnesty program toward the effectiveness of tax revenue at KPP in Indonesia. The data sources in this data are secondary data of tax revenue from all KPP in Indonesia in 2015 and 2016. The samples used in this data are tax revenue from $341 \mathrm{KPP}$ offices. The data analysis methods are descriptive analysis and verification analysis. The hypothesis in this study is tested using paired sample t-test. It shows that tax amnesty does not significantly influence the effectiveness of tax revenue in KPP in Indonesia. The test reveals that out of $341 \mathrm{KPP}$ offices, there are only $53 \mathrm{KPP}$ offices $(16 \%)$ whose tax revenue is effective, whereas the revenue from $288 \mathrm{KPP}$ offices $(84 \%)$ is not yet effective.
\end{abstract}

Key Words: tax amnesty, tax revenue, effectiveness of tax revenue

\begin{abstract}
Abstrak
Penelitian ini bertujuan untuk menguji pengaruh program pengampunan pajak (tax amnesty) terhadap efektivitas penerimaan pajak KPP di Indonesia. Sumber data dalam penelitian ini adalah data sekunder berupa data penerimaan pajak KPP Se-Indonesia Tahun 2015 dan Tahun 2016. Sampel yang digunakan dalam penelitian ini adalah penerimaan pajak yang berasal dari $341 \mathrm{KPP}$. Teknik analisis data yang digunakan ada dua yakni analisis deskriptif dan analisis verifikatif. Untuk menguji hipotesis dalam penelitian ini digunakan uji beda dua sampel berkaitan (paired sample t-test). Hasil penelitian ini menunjukkan bahwa program pengampunan pajak (tax amnesty) tidak memberikan pengaruh yang signifikan terhadap efektivitas penerimaan pajak KPP di Indonesia. Berdasarkan hasil yang diperoleh dari 341 KPP yang tingkat efektivitas penerimaan pajaknya mencapai efektif hanya diraih oleh $53 \mathrm{KPP}(16 \%)$ sedangkan sebagian besarnya sebanyak $288 \mathrm{KPP}$ lainnya atau sebesar $84 \%$ belum mencapai efektif.
\end{abstract}

Kata Kunci: pengampunan pajak, penerimaan pajak, efektivitas penerimaan pajak

Diterima: 12 Januari 2017; $\quad$ Revisi: 22 Februari 2017; $\quad$ Disetujui: 10 Maret 2017 


\section{PENDAHULUAN}

Menurut UU KUP Pasal 1 ayat (1), Pajak adalah kontribusi wajib kepada negara yang terutang oleh orang pribadi atau badan yang bersifat memaksa berdasarkan UndangUndang, dengan tidak mendapatkan imbalan secara langsung dan digunakan untuk keperluan negara bagi sebesar-besarnya kemakmuran rakyat.

Bagi negara, pajak adalah sumber penerimaan negara terbesar dimana pendapatan negara yang berasal dari sektor perpajakan hampir mencapai $80 \%$ dari total penerimaan negara (Supramono \& Damayanti, 2010:1). Hal ini yang kemudian membuat pajak menjadi salah satu sumber penerimaan negara yang sangat penting bagi pelaksanaan dan peningkatan pembangunan nasional yang bertujuan untuk meningkatkan kemakmuran dan kesejahteraan masyarakat. Oleh karena itu sangat diharapkan partisipasi masyarakat untuk ikut berperan aktif memberikan kontribusinya bagi peningkatan pendapatan negara karena pada dasarnya besarnya tingkat penerimaan pajak sangat tergantung pada kontribusi dari wajib pajak tersebut.

Wajib Pajak menurut UU KUP adalah orang pribadi atau badan, meliputi pembayar pajak, pemotong pajak, dan pemungut pajak, yang mempunyai hak dan kewajiban perpajakan sesuai dengan ketentuan peraturan perundang-undangan perpajakan. Kontribusi yang diharapkan dari wajib pajak sangat menentukan berapa besar dan luas tingkat pembangunan yang akan dilakukan. Oleh karenanya pemerintah terus menggenjot aparatur pajak agar dapat mencapai target yang telah ditetapkan.

Target Pendapatan Negara dalam APBN tahun 2016 ditetapkan sebesar Rp 1.822,5 triliun. Dari target Pendapatan Negara tersebut sebesar Rp 1.546,7 triliun ditargetkan bersumber dari Penerimaan Perpajakan dan sebesar Rp 273,8 triliun ditargetkan bersumber dari Penerimaan Negara Bukan Pajak (PNBP). Berdasarkan target tersebut, realisasi pendapatan negara yang sudah dicapai pemerintah Indonesia sampai dengan Bulan Mei 2016 untuk yang bersumber dari Penerimaan Perpajakan telah mencapai sekitar Rp 406,9 triliun dan realisasi pendapatan negara yang bersumber dari Penerimaan Negara Bukan Pajak (PNBP) telah mencapai sekitar Rp 89,1 triliun (Safri, 2016).

Dari hasil tersebut, terlihat bahwa realisasi capaian penerimaan perpajakan baru mencapai 26,3 persen. Hal ini menunjukkan penerimaan dari sektor perpajakan masih rendah dan belum optimal. Mengingat akan pentingnya penerimaan pajak terhadap 
pembangunan nasional maka perlu adanya upaya dari pemerintah khususnya Direktorat Jenderal Pajak guna meningkatkan penerimaan dari sektor perpajakan.

Berkaitan dengan hal itu, maka salah satu bentuk upaya yang ditempuh pemerintah Indonesia guna meningkatkan penerimaan pajak tanpa menambah beban baik jenis pajak baru maupun persentase pajak yang sudah ada kepada masyarakat, dunia usaha dan para pekerja adalah melalui program pengampunan pajak atau tax amnesty.

Tax amnesty merupakan program pengampunan pajak yang diberikan oleh pemerintah kepada wajib pajak berupa penghapusan pajak yang seharusnya terutang, penghapusan sanksi administrasi perpajakan, serta penghapusan dari sanksi pidana di bidang perpajakan yang dimana wajib pajak diminta untuk melaporkan harta yang diperolehnya di Tahun 2015 dan sebelumnya yang belum dilaporkan dalam SPT dengan cara melunasi seluruh tunggakan pajak yang dimiliki serta membayar uang tebusan. Adanya program ini dharapkan dapat memberikan tambahan penerimaan pajak melalui pembayaran tunggakan pajak oleh wajib pajak dan dari uang tebusan yang dibayarkan oleh wajib pajak yang mengikuti program tersebut.

Dasar hukum pelaksanaan tax amnesty ini diatur dalam UU RI Nomor 11 Tahun 2016 tentang Pengampunan Pajak, PMK RI Nomor 118/PMK.03/2016 tentang Pelaksanaan UU Nomor 11 Tahun 2016 tentang Pengampunan Pajak, dan PMK RI Nomor 141/PMK.03/2016 tentang perubahan atas PMK Nomor 118/PMK.03/2016 tentang Pelaksanaan UU Nomor 11 Tahun 2016 tentang Pengampunan Pajak.

Pengampunan pajak atau tax amnesty ini sebenarnya pernah diterapkan Indonesia yakni pada tahun 1964 melalui Penetapan Presiden No. 5 tahun 1964 dan pada tahun 1984 melalui Keputusan Presiden (Kepres) No. 26 tahun 1984 tentang Pengampunan Pajak dan Kepres No. 72 tahun 1984 tentang Perubahan Keputusan Presiden No. 26 tahun 1984 tentang Pengampunan Pajak (Bagiada dan Darmayasa, 2016). Pelaksanaan tax amnesty selama dua periode sebelumnya ini dinilai tidak berjalan efektif. Kurangnya respons dari wajib pajak serta tidak diikuti dengan reformasi sistem administrasi perpajakan secara menyeluruh menyebabkan tidak berjalan efektifnya program tersebut.

Tujuan pemerintah Indonesia kembali memberlakukan kebijakan tax amnesty ini adalah pertama repatriasi atau untuk menarik dana warga negara Indonesia yang ada di luar negeri. Dan kedua untuk meningkatkan basis perpajakan nasional dimana aset yang 
disampaikan dalam permohonan pengampunan pajak dapat dimanfaatkan untuk pemajakan yang akan datang yang nantinya akan berdampak pada efektivitas penerimaan pajak.

Efektivitas penerimaan pajak adalah kemampuan kantor pajak dalam memenuhi target penerimaan pajak berdasarkan realisasi penerimaan pajak. Artinya seberapa jauh kantor pajak dapat mencapai target penerimaan pajak (Ellya Florentin, 2012).

Kantor Pelayanan Pajak merupakan unit kerja dari Direktorat Jenderal Pajak yang melaksanakan pelayanan di bidang perpajakan kepada masyarakat baik yang telah terdaftar sebagai Wajib Pajak maupun yang belum terdaftar sebagai Wajib Pajak. Kantor Pelayanan Pajak yang berada di dalam lingkup wilayah kerja Direktorat Jenderal Pajak ada sebanyak 341 Kantor Pelayanan Pajak yang masing-masing tersebar di wilayah Indonesia. Masingmasing Kantor Pajak tersebut setiap tahunnya telah menetapkan target penerimaan pajak dan dievaluasi kinerjanya berdasarkan realisasi penerimaan pajak yang diperoleh.

Dari data yang diperoleh, realisasi penerimaan pajak oleh 341 kantor pajak sampai dengan Bulan Juni 2016 rata-rata belum dapat memenuhi 50\% dari target penerimaan pajak yang ditentukan (Sumber: KPP Pratama Gorontalo). Hal ini dapat disimpulkan bahwa penerimaan pajak untuk seluruh KPP se-Indonesia belum dapat dikatakan efektif.

Berangkat dari permasalahan tersebut memberikan motivasi penulis untuk melakukan penelitian yang bertujuan untuk menguji apakah dengan diberlakukannya program pengampunan pajak (tax amnesty) oleh pemerintah ini dapat memberikan pengaruh terhadap efektivitas penerimaan pajak seluruh KPP diIndonesia.

\section{KERANGKA TEORITIS}

\section{Pajak}

Soemitro dalam Mardiasmo (2011:1) mengutarakan bahwa pajak adalah iuran rakyat kepada kas negara berdasarkan undang-undang (yang dapat dipaksakan) dengan tiada mendapat jasa timbal (kontraprestasi) yang langsung dapat ditunjukkan dan yang digunakan untuk membayar pengeluaran umum. Andriani dalam Agoes (2014:6) mengutarakan bahwa pajak adalah iuran kepada negara (yang dapat dipaksakan) yang terutang oleh yang wajib membayarnya menurut peraturan-peraturan, dengan tidak mendapat prestasi kembali, yang langsung dapat ditunjuk, dan yang gunanya adalah untuk membiayai pengeluaranpengeluaran umum berhubung dengan tugas negara untuk menyelenggarakan pemerintahan. 


\section{Pengampunan Pajak (Tax Amnesty)}

Menurut PMK RI Nomor 118/PMK.03/2016 tentang Pelaksanaan UU Nomor 11 Tahun 2016 tentang Pengampunan Pajak Pasal 2 ayat 1, menjelaskan bahwa yang dimaksud Pengampunan Pajak adalah penghapusan pajak yang seharusnya terutang, tidak dikenai sanksi administrasi perpajakan dan sanksi pidana di bidang perpajakan, dengan cara mengungkap harta dan membayar uang tebusan.

\section{Efektivitas Penerimaan Pajak}

Menurut Ellya Florentin (2012) menyatakan efektivitas diartikan seberapa jauh tercapainya suatu tujuan yang terlebih dahulu ditentukan. Suatu usaha atau kegiatan dapat dikatakan efektif apabila usaha atau kegiatan tersebut telah mencapai tujuannya. Apabila konsep efektivitas dikaitkan dengan penerimaan pajak maka efektivitas penerimaan pajak adalah kemampuan kantor pajak dalam memenuhi target penerimaan pajak berdasarkan realisasi penerimaan pajak. Artinya seberapa jauh kantor pajak dapat mencapai target penerimaan pajak yang sudah ditetapkan.

\section{METODE}

Penelian ini dilakukan pada seluruh Kantor Pelayanan Pajak (KPP) di Indonesia. Metode penelitian yang digunakan dalam penelitian ini adalah metode penelitian kuantitatif. Metode penelitian kuantitaif adalah metode yang digunakan untuk menganalisis apakah variabel independen $(\mathrm{X})$ berpengaruh atau tidak terhadap variabel dependen $(\mathrm{Y})$. Dimana variabel independen $(\mathrm{X})$ adalah variabel yang mempengaruhi variabel dependen entah secara positif maupun negatif. Sedangkan variabel dependen $(Y)$ merupakan variabel yang menjadi perhatian utama peneliti. Objek penelitian ini yaitu program pengampunan pajak (tax amnesty) dan efektivitas penerimaan pajak. Data yang digunakan dalam penelitian ini adalah data sekunder berupa data penerimaan pajak seluruh KPP di Indonesia pada tahun 2015-2016. Populasi dalam penelitian ini sebanyak 341 KPP dan keseluruhan KPP tersebut dijadikan sampel dalam penelitian ini.

\section{HASIL DAN PEMBAHASAN}

Analisis Deskriptif Pelaksanaan Program Pengampunan Pajak (Tax Amnesty) di

\section{Indonesia}

Pelaksanaan program pengampunan pajak (tax amnesty) di Indonesia berjalan dengan efektif dan mendapat respon yang baikdari para Wajib Pajak. Berdasarkan data yang diperoleh, total WP yang mengikuti tax amnesty sampai dengan periode terakhir per 31 
Maret 2017 mencapai 832.631 WP. Adapun rinciannya adalah 374.624 WP orang pribadi non UMKM, 265.864 WP orang pribadi UMKM, 111.181 WP badan non UMKM, dan 80.962 WP badan UMKM.

Total harta berdasarkan surat pernyataan harta (SPH) yang disampaikan oleh WP mencapai Rp 4.704 triliun. SPH itu terdiri atas deklarasi dalam negeri Rp 3.528 triliun, deklarasi luar negeri Rp 1.030 triliun, dan repatriasi Rp 146 triliun. Selanjutnya, jumlah uang tebusan berdasarkan SPH yang disampaikan dalam program amnesti pajak mencapai Rp 110 triliun. Tebusan itu terdiri atas orang pribadi non-usaha mikro, kecil, dan menengah (UMKM) Rp 88,6 triliun, orang pribadi UMKM Rp 7,19 triliun, badan non-UMKM Rp 13,4 triliun, dan badan UMKM mencapai Rp 0,53 triliun.

Sedangkan realisasi berdasarkan surat setoran pajak (SSP) yang diterima mencapai Rp 125 triliun. Hal itu terdiri atas pembayaran tebusan senilai Rp 111 triliun, pembayaran tunggakan Rp 13 triliun, dan pembayaran bukti permulaan (bukper) Rp 1,15 triliun.

\section{Analisis Deskriptif Tingkat Efektivitas Penerimaan Pajak KPP Se-Indonesia Pasca} Tax Amnesty

Tingkat efektivitas penerimaan pajak oleh 341 KPP di Indonesia pasca tax amnestydapat dilihat dalam gambar berikut ini :

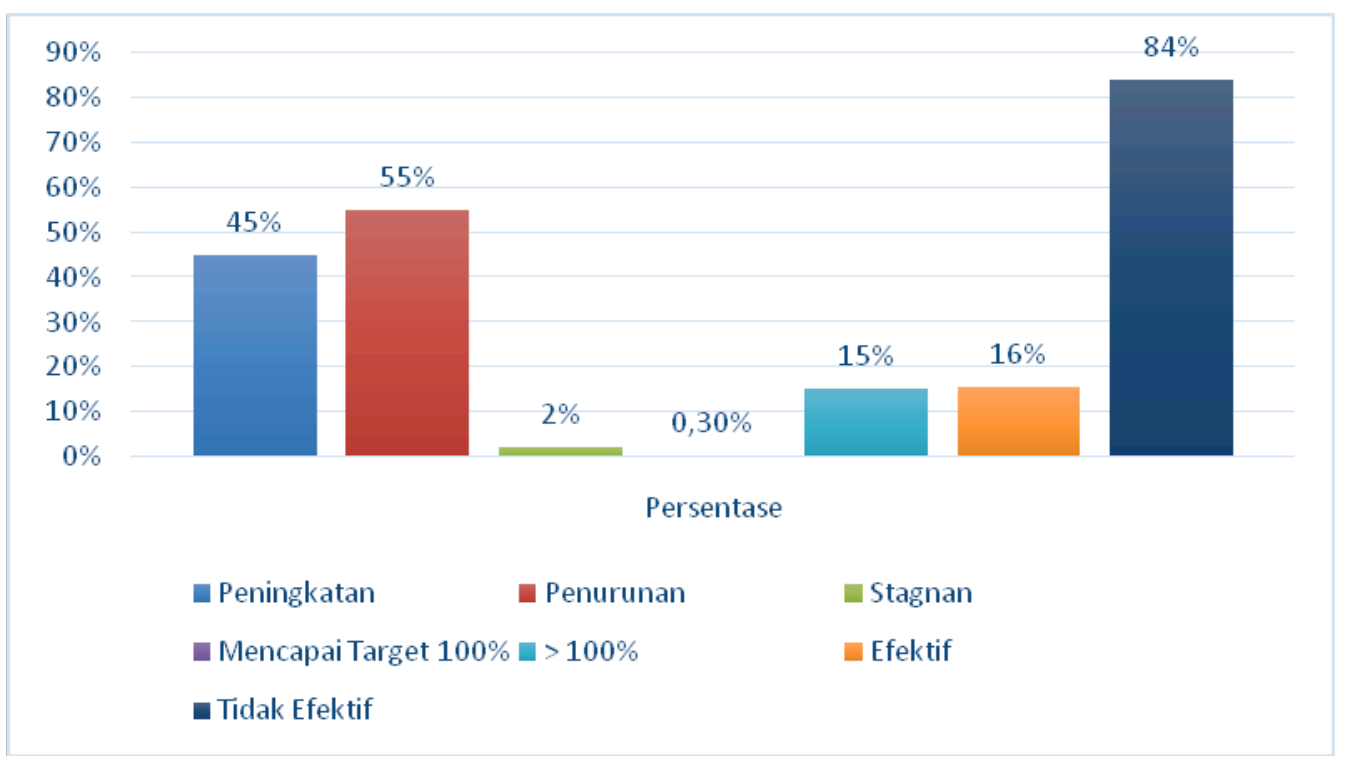

Gambar 1.

Efektivitas Penerimaan Pajak 
Berdasarkan Gambar 1 terlihat bahwa dari keseluruhan KPP di Indonesia berjumlah 341 KPP yang tingkat efektivitas penerimaan pajaknya dapat dikatakan efektif hanya diraih oleh 53 KPP. Sedangkan sebagian besarnya sebanyak 288 KPP lainnya tingkat efektivitas penerimaan pajaknya belum dapat mencapai efektif. Selain itu secara total keseluruhan tingkat efektivitas penerimaan pajak di Indonesia masih menunjukkan hasil yang sama dengan capaian sebelumnya yakni masih tetap berada pada angka $82 \%$.

Tabel 3

\section{Hasil Uji Homogenitas Varians Data Penelitian}

Descriptive Statistics

\begin{tabular}{|l|r|r|r|r|r|r|}
\hline & \multicolumn{1}{|c|}{$\mathrm{N}$} & \multicolumn{1}{|c|}{ Minimum } & Maximum & \multicolumn{1}{c|}{ Mean } & Std. Deviation & Variance \\
\hline Efektivitas Penerimaan & 342 & .56 & 1.31 & .8326 & .11397 & .013 \\
$\begin{array}{l}\text { Pajak Tahun 2015 } \\
\text { Efektivitas Penerimaan } \\
\text { Pajak Tahun 2016 }\end{array}$ & 342 & .39 & 4.18 & .8555 & .26677 & .071 \\
Valid N (listwise) & 342 & & & & & \\
\hline
\end{tabular}

Dari informasi tersebut dapat ditentukan nilai F-hitung sebesar :

$$
\begin{aligned}
F & =\frac{\text { varians terbesar }}{\text { varians terkecil }} \\
& =\frac{0,071}{0,013} \\
& =5,462
\end{aligned}
$$

Dari perhitungan tersebut diperoleh nilai F-hitung sebesar 5,462. Sedangkan nilai F-tabel dengan menggunakan $\boldsymbol{\alpha}$ sebesar 0.05 dan derajat kebebasan untuk pembilang dan penyebut masing-masing sebesar 341 adalah sebesar 1,195. Dari hasil ini dapat dilihat bahwa nilai F-hitung yang diperoleh lebih besar dari nilai F-tabel sehingga Ho ditolak. Dengan demikian dapat disimpulkan bahwa varians antara efektivitas penerimaan pajak sebelum dan sesudah program tax amnesty tidak bersifat homogen.

Dalam pengujian statistik menunjukkan bahwa nilai t-stat untuk perbedaan efektivitas penerimaan pajak sebelum dan sesudah program tax amnesty adalah sebesar 1,743. Sedangkan nilai t-tabel pada tingkat signifikansi 5\% dan derajat bebas sebesar 341 adalah sebesar 1,967 . 
Tabel 4

Hasil Uji Paired Sample Test

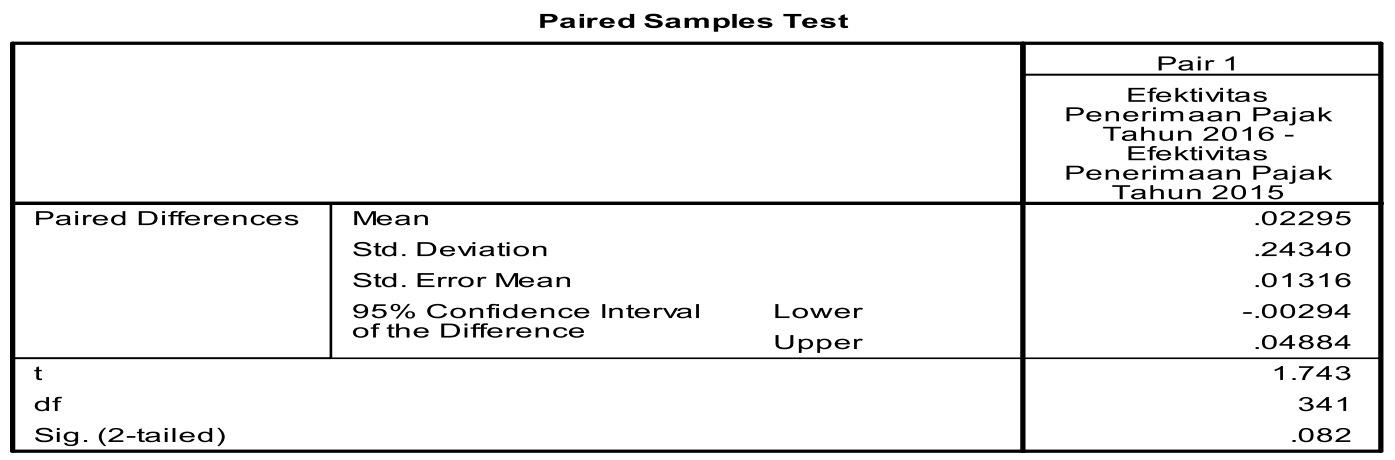

Karena nilai t-hitung yang diperoleh yakni sebesar 1,743 berada pada daerah penerimaan Ho maka dengan demikian dapat dikatakan bahwa hasil pengujian menunjukkan bahwa pada tingkat keyakinan 95\% kesimpulan yang diambil adalah menerima Ho dan menolak H1. Dengan demikian dapat disimpulkan bahwa tidak terdapat perbedaan yang signifikan antara efektivitas penerimaan pajak baik sebelum dan sesudah program tax amnesty. Dengan kata lain, program tax amnesty tidak memberikan pengaruh yang signifikan terhadap efektivitas penerimaan pajak KPP di Indonesia.

\section{Pembahasan}

Berdasarkan hasil analisis deskriptif pengaruh pelaksanaan program pengampunan pajak (tax amnesty) terhadap efektivitas penerimaan pajak KPP Se-Indonesia menunjukkan hasil bahwa pelaksanaan program tax amnesty mampu memberikan tambahan penerimaan pajak yang pada gilirannya dapat berdampak pada capaian efektivitas penerimaan pajak. Namun hasil dari pelaksanaan tax amnesty ini tidak memberikan dampak sepenuhnya terhadap efektivitas penerimaan pajak yang diperoleh KPP di Indonesia.

Dari hasil analisis deskriptif tingkat efektivitas penerimaan pajak diperoleh hasil bahwa dari 341 KPP yang tingkat efektivitas penerimaan pajaknya dapat dikatakan efektif hanya diraih oleh $53 \mathrm{KPP}$ atau jika dipersentasekan dari jumlah KPP yang ada tingkat efektivitas penerimaan pajaknya mencapai efektif hanya diraih oleh sebanyak 16\% KPP, sedangkan sebagian besarnya sebanyak 288 KPP lainnya atau sebesar $84 \%$ belum dapat mencapai efektif. Hal yang menyebabkan tidak tercapainya penerimaan pajak yang efektif dikarenakan melonjaknya target penerimaan pajak yang ditetapkan oleh masing-masing KPP sehingga belum dapat mencapat target yang diinginkan. Selain itu hasil analisis deskriptif tesebut juga senada dengan hasil analisis verifikatif yang menggunakan pengujian 
statistik. Berdasarkan hasil pengujian statistik diperoleh hasil serupa yang menunjukkan bahwa tidak terdapat perbedaan yang signifikan antara efektivitas penerimaan pajak baik sebelum dan sesudah program tax amnesty.

Dengan demikian dapat disimpulkan bahwa hasil dalam penelitian ini menunjukkan bahwa program pengampunan pajak (tax amnesty) tidak memberikan pengaruh yang signifikan terhadap efektivitas penerimaan pajak KPP di Indonesia.

\section{SIMPULAN}

Program pengampunan pajak (tax amnesty) tidak memberikan pengaruh yang signifikan terhadap efektivitas penerimaan pajak KPP di Indonesia. Berdasarkan hasil yang diperolehdari $341 \mathrm{KPP}$ yang tingkat efektivitas penerimaan pajaknya mencapai efektifhanya diraih oleh 53 KPP (16\%) sedangkan sebanyak 288 KPP lainnya (84\%) belum mencapai efektif.

Saran yang diajukan dalam penelitian ini ialah: (1) Untuk KPP yeng tingkat efektivitas penerimaan pajaknya belum dapat mencapai efektif disarankan dalam menentukan target sebaiknya disesuaikan dengan potensi penerimaan yang ada selain itu untuk para petugas pajak hendaknya selalu berkompeten dan professional dalam mengemban tugas mengumpulkan pajak Negara. Kemudian bagi KPP yang tingkat efektivitas penerimaan pajaknya mencapai efektif untuk kedepannya diharapkan bisa dipertahankan. (2) Selanjutnya diharapkan KPP bisa memberikan penyuluhan / sosialisasi yang menyeluruh kepada seluruh lapisan masyarakat guna meningkatkan kesadaran WP dalam kejujuran melaporkan laporan keuangannya dan membayarkan pajak terutangnya yang nantinya diperuntukkan untuk penerimaan Negara. (3) Untuk peneliti selanjutnya yang ingin melakukan penelitian sejenis diharapkan untuk dapat memperpanjang rentang waktu penelitian karena dalam penelitian ini penulis hanya menggunakan data sebanyak dua tahun yaitu data tahun 2015 dan 2016.

\section{PUSTAKA ACUAN}

Agoes, Sukrisno dan Estralita Trisnawati. 2014. Akuntansi Perpajakan.Edisi 3. Jakarta: Salemba Empat.

Bagiada, I Made dan I Nyoman Darmayasa. 2016. Tax Amnesty Upaya Membangun Kepatuban Sukarela. Simposium Nasional Akuntansi Vokasi V, Mei. 
Florentin Listyaningtyas, Ellya. 2008. Efektivitas Pelaksanaan Pemeriksaan Dalam Rangka Meningkatkan Penerimaan Negara Dari Sektor Pajak (Studi Kasus Di KPP Tulungagung). Skripsi Universitas Negeri Surabaya.

Mardiasmo. 2011. Perpajakan. Edisi Revisi 2011. Yogyakarta: Andi.

Republik Indonesia. Undang - Undang Nomor 28 tahun 2007 Tentang Ketentuan Umum dan Tata Cara Perpajakan

Republik Indonesia. PMK RI Nomor 118/PMK.03/2016 Tentang Pelaksanaan Undang Undang Nomor 11 Tahun 2016 Tentang Pengampunan Pajak

Safri. 2016. Efektifitas Program Tax Amnesty dan Faktor Keberbasilannya: Pembelajaran dari Negara - Negara yang pernah Menerapkan

Supramono, Damayanti. 2010. Perpajakan Indonesia. Yogyakarta: CV. ANDI 